УДК: 616.831-001.8-092.8-053.31/.32-

039.72:616.155.1-007.1-085.273.2:615.21

DOI: 10.24061/2413-4260.X.1.35.2020.8

\section{Л. Д. Танцюра}

Национальная медицинская академия

последипломного образования имени П. Л. Шупика

МЗ Украины (г. Киев, Украина)

\section{ПЕРИНАТАЛЬНАЯ АСФИКСИЯ: \\ ВАРИАНТЫ ГИБЕЛИ КЛЕТОК И НЕЙРОПРОТЕКТИВНЫЕ СВОЙСТВА ЭРИТРОПОЭТИНА}

\title{
Резюме
}

Перинатальная асфиксия является важным фактором риска развития неврологического дефицита и когнитивных нарушений у новорожденных детей. В остром периоде, после перенесенной гипоксии-ишемии, в головном мозге происходит необратимая гибель части клеток по типу некроза. Поврежденные таким образом клетки уже не могут быть восстановлены. Во вторую фазу повреждения, которая обусловлена вторичной энергетической недостаточностью, варианты гибели клеток включают апоптоз, аутофагию, партанатос и ферроптоз. Эти типы разрушения клеток являются регулируемыми, они могут модулироваться, в том числе и фармакологическими средствами. Препаратом, который продемонстрировал свои нейропротективные свойства и улучшение нейро-когнитивных исходов у новорожденных детей после перенесенной гипоксииишемии, выявился эритропоэтин. Результаты исследований среди недоношенных детей противоречивы. Улучшение когнитивного развития недоношенных детей при раннем профилактическом назначении рекомбинантного человеческого эритропоэтина получено у детей с гестационным возрастом более 28 ми недель. У глубоконедоношенных детей, рожденных в сроке менее 28-ми недель гестации, применение эритропоэтина не оказало какого-либо влияния на дальнейшие исходы при оценке к 2-х летнему возрасту. У доношенных новорожденных применение эритропоэтина в ранние сроки после перенесенной гипоксииишемии сокращает риск развития церебрального паралича и когнитивных нарушений. Продолжающиеся исследования призваны получить информачию о влиянии раннего использования эритропоэтина на исходы как недоношенных детей, так и доношенных новорожденных при сочетании эритропоэтина и лечебной гипотермии.

Ключевые слова: эритропоэтин; повреждение головного мозга; нейропротекиия; новорожденные дети; гипоксически-ишемическая эниефалопатия; апоптоз; некроз; аутофагия.

Перинатальная асфиксия является одной из основных причин летальных исходов у новорожденных детей. У выживших сохраняется высокий риск неврологического дефицита и когнитивных нарушений. Современные доказательства свидетельствуют об эффективности лечебной гипотермии после перенесенной перинатальной асфиксии. Было доказано, что в результате использования краниоцеребральной или общей гипотермии происходило сокращение летальности без увеличения частоты неврологических нарушений у выживших детей. Однако, несмотря на улучшение исходов после начала использования лечебной гипотермии, сохраняется до 25\% детей с различной степенью неврологического дефицита после перенесенной перинатальной асфиксии [1]. Именно поэтому продолжается поиск веществ или стратегий, которые могли бы оказывать нейропротективное действие и улучшать нейрокогнитивное развитие новорожденных с гипоксическиишемической энцефалопатией. Препаратом, который продемонстрировал такие свойства, оказался эритропоэтин.

Особенности повреждения головного мозга у новорожденных детей.

Среди множества этиологических факторов повреждения головного мозга у новорожденных детей ведущим является гипоксически-ишемическия энцефалопатия у доношенных новорожденных и перивентрикулярная лейкомаляция у недоношенных детей.

В сравнении с взрослым мозгом, мозг новорожденного имеет высокий уровень потребления кислорода, высокие концентрации ненасыщенных жирных кислот и низкие концентрации антиоксидантов, что делает его особенно чувствительным к окислительным повреждениям [2].

Возникновение

гипоксически-ишемической энцефалопатии у доношенных детей связывают с нарушением перфузии и оксигенации ткани головного мозга, которые возникают после перинатальной асфиксии. В своем развитии она проходит несколько фаз. Начальная фаза связана с нарушением доставки кислорода. Организм переходит на анаэробный тип метаболизма, при котором существенно уменьшается образование энергетических субстратов, в частности, аденозинтрифосфата (АТФ) и фосфокретина. Дефицит энергии приводит к нарушению работы мембранных насосов, что ведет к накоплению в клетке ионов натрия и кальция, развитию цитотоксического отека головного мозга, высвобождению возбуждающих нейротрансмиттеров (глутамат) и накоплению свободных жирных кислот [3].

Вторая фаза обусловлена вторичной энергетической недостаточностью и развивается на протяжении 6 - 48 часов после первоначального повреждения. Это стадия реперфузионных повреждений связана с продукцией токсических веществ, в том числе и таких как свободные радикалы. В эту фазу фиксируется воспаление, митохондриальная дисфункция, усиливается си- 
нтез оксида азота, продолжает усугубляться цитотаксический отек головного мозга. Основная гибель клеток происходит в результате изменений, происходящих во вторую стадию повреждения мозга. Характер повреждения включает повреждение глубокого серого вещества мозга (базальные ганглии и таламус) и поликистозную энцефалопатию [4].

В поисках нейротротективных стратегий именно на вторую стадию реперфузинного повреждения направлены большинство усилий. На сегодняшний день единственным нейропротекивным средством с доказанной эффективностью является лечебная гипотермия. Еe использование включено в международные рекомендации по сердечнолегочной реанимации. Применять лечебную гипотермию рекомендуют на протяжении первых 72 часов после перенесенной асфиксии.

Негативные неврологические исходы у глубоконедоношенных детей связаны как с прерыванием нормального развития головного мозга, так и повреждением, вызванным перинатальной гипоксией-ишемией. В третьем триместре беременности происходит быстрое увеличение размера, формы и усложнение структуры головного мозга. Специфическим, особо уязвимым структурным элементом мозга является зародышевый матрикс, который в постнатальном периоде у недоношенных детей может служить источником внутричерепного кровоизлияния [5].

В этот же период происходит активное развитие олигодендроцитов. Несмотря на то, что в последнее время наблюдается сокращение частоты тяжелых внутричерепных кровоизлияний и перивентрикулярной лейкомаляции, неврологические исходы, особенно у глубоконедоношенных детей, остаются неизменными [6].

Классически считается, что у недоношенных детей существует наибольший риск повреждения белого вещества мозга из-за уязвимости развития олигодендроцитов. Однако по результатам недавних исследований показано, что также нарушается и дендритогенез, что приводит к уменьшению объема как белого, так и серого вещества мозга [7].

\section{Варианты гибели клеток}

Гибель клетки происходит разными путями. Для разработки новых методов нейропротекции необходимо понимать, какие механизмы лежат в основе необратимого повреждения клеток при гипоксически-ишемической энцефалопатии [8].

Выделяют два варианта гибели клеток:

1) Внезапная гибель клетки, фактически мгновенное неконтролируемое состояние, связанное с физическим повреждением плазматической мембраны, вызванной экстремальным физическим, химическим или механическим воздействием. К такому виду повреждения относят некроз. Поврежденные таким образом клетки уже не могут быть восстановлены. Гибель клетки по типу некроза происходит практически сразу после воздействия повреждающего фактора, например, острой гипоксии-ишемии.

2) Регулируемая гибель клетки, которая дифференцирована по многим типам. Согласно данным Номенклатурного комитета по изучению гибели клеток выделяется 13 вариантов смерти клеток [9]. Варианты, которые встречаются после перинатального повреждения мозга, включает в себя некроз, апоптоз, аутофагию, партанатос и ферроптоз. Наиболее хорошо изученными являются некроз, апоптоз и аутофагия. Гибель клеток посредством партанатоса и ферроптоза изучена пока недостаточно.

Регулируемая смерть (не одно и то же, что запрограммированная гибель клеток, термин, который используется как синоним апоптоза) подразумевает запуск процесса гибели клетки путем активации или угнетения отдельных структурных элементов клетки. И запущенный таким образом процесс разрушения клетки может модулироваться фармакологическими средствами [10].

Регулируемая гибель клеток обычно происходит c некоторой задержкой, в ситуациях, когда эндогенные защитные механизмы не способны восстановить клеточный гомеостаз.

В развивающемся головном мозге новорожденного ребенка повреждение клетки может быть запущено гипоксией, гипероксией, гипоксиейишемией, травмой, воспалением / инфекцией [8]. Механизм гибели клетки, который будет запущен, зависит от метаболического состояния, тяжести повреждения / состояния, типа клетки, гестационного возраста ребенка и др.

Наиболее изученным механизмом повреждения клеток в перинатальном периоде является гипоксияишемия. При этом состоянии происходит истощение высокоэнергетических фосфатов, особенно АТФ и фосфокреатина. Со временем, постепенно их уровень возвращается к норме. Но эти нарушения сопровождаются длительным истощением энергетических резервов, что способствует гибели клеток и дальнейшему повреждению головного мозга [11].

Апоптоз является формой запрограммированной гибели клетки и характеризуется иммунологически «тихим» сморщиванием клетки, пикнозом ядра и интактной мембраной клетки. Апоптоз может быть активирован внутренними или внешними путями. Внутренний, или митохондриальный, зависит от баланса анти- и про-апоптических белков. Внешний путь апоптоза запускается внеклеточными сигналами и вызывает активацию проапоптических рецепторов на поверхности клетки.

Аутофагия - это гомеостатический процесс, при котором нежелательные белки и поврежденные органеллы удаляются из клеток путем образования аутофагосом [12]. Аутофагосома сливается с лизосомами клетки с образованием аутофаголизосомы. На заключительной стадии процесса содержимое аутофаголизосомы под действием лизосомальных гидролаз разрушается, a содержимое аутофагосомы в дальнейшем используется повторно для метаболических потребностей клетки.

Аутофагия в первую очередь действует как защитный механизм, который может предотвратить гибель клеток. Она может уменьшить апоптоз, удаляя поврежденные митохондрии из клетки, или может сама по себе быть самостоятельным механизмом гибели клеток, который взаимосвязан как с некрозом, так и с апоптозом. Существуют механизмы, которые могут как подавлять, так и 
стимулировать аутофагию. Поэтому одним из новых подходов к нейропротекции является влияние на процесс аутофагической гибели клеток [13].

Аутофагия наблюдается при различных физиологических и патологических состояниях, таких как нормальное развитие, недостаток питательных веществ, нейродегенерация, иммунитет и старение [14]. Отличительной чертой аутофагической гибели клеток является накопление аутофагических вакуолей лизосомального происхо-ждения.

Принимая во внимание, что базовый уровень аутофагии необходим для благополучия клеток, особенно нейронов, его индукция может привести к противоположным эффектам в зависимости от уровня активации, стимула и типа клеток [15].

Самая известная роль усиленной аутофагии - это защитная реакция, способствующая выживанию клеток путем предоставления альтернативного источника энергии в клетках, лишенных питательных веществ. Это механизм, который способствует выживанию благодаря способности уничтожать токсичные метаболиты или внутриклеточные патогены [16]. Тем не менее, в патологических ситуациях аутофагия может способствовать гибели клеток.

Дуальная роль аутофагии особенно важна для нейронов. В центральной нервной системе чрезмерно низкая базальная активность процесса аутофагии, что приводит к сокращению оборота / обмена белков внутри клетки, что является фактором риска развития нейродегенеративных заболеваний [17]. Напротив, избыточно активная аутофагия зафиксирована при гибели клеток, которая происходит естественным образом в период морфогенеза или при острых неврологических расстройствах, к которым относят и гипоксиюишемию [18].

Аутофагия может быть вовлечена в гибель клеток одним из двух способов: в качестве триггера апоптотической или некротической гибели клеток или, реже, как независимый молекулярный механизм гибели клеток, морфологически отличающийся от апоптоза и некроза. В последнем случае происходит избыточная активация аутофагии, что приводит к деградации важных структурных элементов клетки или даже ее ядра [19]. Усиленную аутофагию можно рассматривать как автономный путь гибели клеток, если его ингибирование уменьшает или замедляет гибель клеток при отсутствии признаков апоптоза или некроза.

Однако на сегодняшний день нет четкого понимания, какие механизмы запускают эти оба пути. При гипоксически-ишемических состояниях чаще наблюдаются смешанные формы гибели клеток, имеющие общие аутофагические и апоптические признаки [20].

Для разработки новых терапевтических подходов необходимо понимать, какие патологические процессы происходят после перенесенной перинатальной асфиксии и морфологические особенности гибели клеток после перенесенной гипоксии-ишемии, а также временные рамки течения того или иного состояния. Согласно результатам исследований в модели перинатальной церебральной гипоксии-ишемии наиболее часто встречаются некроз, апоптоз и аутофагия. В процесс гибели нейрона могут быть вовлечены все указанные виды смерти клетки. Для поиска нейропротективных средств необходимо понимать, почему, когда и каким образом погибает нейрон после перинатальной асфиксии [21].

При повреждениях головного мозга у новорожденных были обнаружены несколько иных видов гибели клеток, включая ферроптоз. Этот тип разрушения клетки является железо-зависимой, неапоптической формой гибели клеток, которая характеризуется ранним перекисным окислением липидов и отличается от других форм регулируемой гибели клеток с точки зрения ее генетических компонентов, специфических морфологических особенностей и биохимических механизмов [22].

Ферроптоз был впервые описан в мутантных раковых клетках в 2012 году и был определен как железо- и липид-зависимая форма перекисного окисления клеток, которая генетически, биохимически, морфологически и механически отличается от других типов гибели клеток.

Наряду с перивентрикулярной лейкомаляцией, одним из наиболее часто встречаемых повреждений головного мозга у недоношенных детей являются внутричерепные кровоизлияния. Такое повреждение мозга характеризуется первичным повреждением, вызванным присутствием кровоизлияния, и вторичным повреждением, связанным с действием нейротоксичных соединений, высвобождаемых из гематомы, включая свободное железо и внеклеточный гемоглобин. Аккумуляция железа способствует дилатации желудочков мозга [23]. Интересно, что при повреждениях головного мозга у новорожденных при использовании хелаторов железа и эритропоэтина был продемонстрирован нейропротективный эффект.

\section{Механизм нейропротекторного действия эритропоэтина}

Эритропоэтин - это гликопротеин с молекулярной массой 30,4 кДа. Пренатально синтезируется в печени. После рождения секретируется почками в ответ на гипоксию и является основным гемопоэтическим фактором роста, ответственным за эритропоэз. Кроме этого, в ответ на гипоксию эритропоэтин также вырабатывается и в мозге. Его синтез происходит в астроцитах, олигодендроцитах, клетках микроглии и нейронах. Усиленный выброс эритропоэтина в ответ на гипоксию является естественной реакцией организма [21].

В головном мозге он действует как нейропротективное вещество, оказывая антиапоптотическое действие посредством связывания с рецепторами эритропоэтина на зрелых нейронах, предшественниках нейронов и других клетках, что приводит к индукции антиапоптотических генов, Bcl-2 и Bcl-xL [24]. Также эритропоэтин обладает противовоспалительным, нейротропным и антиоксидантным действием, уменьшая циркуляцию свободного железа путем его включения в эритропоэз. Указанные процессы способствует нейрогенезу, ремоделированию ткани головного мозга и обеспечению пластичности после перенесенной гипоксии-ишемии [25].

Эритропоэтин ослабляет эффекты воспаления, уменьшая реактивный астроцитоз и активацию микроглии, и уменьшает / минимизирует действие медиаторов воспаления, уменьшая количество 
иммунных клеток в поврежденной области. Это способствует ограничению степени ишемического повреждения.

Доказательства эффективности эритропоэтина как нейропротектора

C увеличением выживаемости глубоконедоношенных детей одной из основных задач неонатологии является улучшение их дальнейшего неврологического развития. Одним из перспективных веществ, продемонстрировавших позитивное влияние на дальнейшее развитие недоношенных детей, выявился эритропоэтин. В последние годы появились доказательства эффективности эритропоэтина как у доношенных, так и недоношенных детей.

Согласно результатам недавно проведенного метаанализа было показано, что раннее профилактическое использование рекомбинантного человеческого эритропоэтина улучшает когнитивное развитие недоношенных детей к 18-24-м месяцам скоррегированного возраста [26]. В метаанализ были включены четыре рандомизированных контролированных исследования, в которых принимали участие недоношенные дети с гестационным возрастом 27 - 30 нед. Следует отметить, что эритропоэтин назначали в возрасте от 3-х до 96-и часов жизни. Но по данным представленного метаанализа назначение эритропоэтина не влияло на моторное развитие ребенка, нарушения зрения и слуха.

Однако, по данным недавно опубликованного многоцентрового рандомизированного двойного слепого исследования PENUT (Preterm Erythropoietin Neuroprotection Trial) назначение эритропоэтина с целью нейропротекции глубоконедоношенным детям с гестационным возрастом 24 недели и 0 суток - 27 недель и 6 суток не продемонстрировало преимущества в сравнении с плацебо [27]. Эритропоэтин начинали вводить в первые сутки жизни внутривенно в дозе 1000 ЕД на килограмм массы тела каждые 48 часов в общей сложности шесть доз с последующей поддерживающей дозой 400 ЕД на килограмм три раза в неделю подкожно до достижения полных 32-х недель постконцептуального возраста. В качестве плацебо использовали физиологический раствор натрия хлорида.

Значимых различий междугруппой эритропоэтина и группой плацебо по частоте летальных исходов или тяжелого нарушения развития нервной системы в возрасте 2 лет не зафиксировано. Также не обнаружено статистически значимых различий между группами по частоте развития ретинопатии недоношенных, внутричерепного кровоизлияния, сепсиса, некротического энтероколита, бронхолегочной дисплазии.

Одной из возможных причин отсутствия какихлибо позитивных результатов от применения эритропоэтина в исследование PENUT является тот факт, что дети, включенные в исследование, имели меньший гестационный возраст, чем дети, результаты которых анализировались в метаанализе.

Результаты продолжающихся исследований, возможно, предоставят новые доказательства относительно эффективности раннего использования эритропоэтина как нейропротектора у недоношенных детей.

Современные рекомендации по ведению доношенных новорожденных детей, перенесших перинатальную гипоксию-ишемию, включают проведение лечебной гипотермии. Однако несмотря на улучшение исходов детей, лечившихся с использованием терапевтической гипотермии, у значительной части этих детей сохраняется неврологический дефицит разной степени выраженности [1].

Согласно результатам недавно выполненного метаанализа при раннем назначении эритропоэтина без использования лечебной гипотермии доношенным новорожденным с умеренной и тяжелой гипоксически-ишемической энцефалопатией сокращался риск развития церебрального паралича и когнитивных нарушений [28].

При анализе состояния мозга по данным магнитно-резонансной терапии было показано уменьшение риска повреждения головного мозга у детей, получавших эритропоэтин с использованием или без применения гипотермии. Также была получена тенденция сокращения летальности при назначении эриропоэтина с использованием или без применения охлаждения. Средняя кумулятивная доза эритропоэтина в анализируемых исследованиях составила 2750 ЕД/кг $(2100$ - 5000 ЕД/кг).

На сегодняшний день остается открытым вопрос о сочетании лечебной гипотермии и эритропоэтина, как двух терапевтических вмешательств с доказанной эффективностью, оказывающих нейропротекивное воздействие. Вполне вероятно, что можно было бы ожидать существенное сокращение частоты нежелательных последствий после перинатальной асфиксии при сочетании эритропоэтина и лечебной гипотермии в сравнении c монотерапией эритропоэтином и монотерапией гипотермии. Данные РКИ показывают, что абсолютный риск смерти или неврологического дефицита ниже у детей, получающих эритропоэтин в сочетании с гипотермией (16,7\% при использовании эритропоэтина против $38,5 \%$ в группе плацебо) [29] по сравнению с монотерапией эритропоэтином $(24,6 \%$ в группе применения эритропоэтина против 43,8\% в группе плацебо) [30].

Заключение. На сегодняшний день нейропротективные свойства эритропоэтина продолжают изучаться. Имеющиеся на сегодняшний день доказательства эффективности у недоношенных детей противоречивы. У детей с гестационным возрастом более 28 недель раннее использование эритропоэтина сопровождалось улучшением когнитивных исходов. Тогда как у глубоконедоношенных детей, рожденных в сроке до 28 недель гестации, применение эритропоэтина не оказало какого-либо влияния на дальнейшие исходы при оценке к 2-х летнему возрасту. Продолжающиеся исследования предоставят информацию о влиянии раннего использования эритропоэтина на неврологические исходы недоношенных детей.

Совершенно иные результаты получены при раннем использовании эритропоэтина у доношенных новорожденных, перенесших перинатальную гипоксию-ишемию. Было получено сокращение риска повреждения головного мозга и уменьшение частоты неврологических и когнитивных 
расстройств, получена тенденция к сокращению летальности. Поскольку в настоящее время терапевтическая гипотермия является стандартом терапии перинатальной асфиксии, продолжающиеся исследования призваны получить информацию о влиянии на исходы новорожденных детей сочетания эритропоэтина с лечебной гипотермией.

Конфликт интересов. Автор заявляет об отсутствии конфликта интересов.

\section{Источники финансирования:}

Самофинансирование.

\section{Література}

1. Jacobs SE, Berg M, Hunt R, Tarnow-Mordi WO, Inder TE, Davis

PG. Cooling for newborns with hypoxic ischaemic encephalopathy. Cochrane Database Syst Rev[Internet]. 2013[cited 2019 Aug 19];1:Cd003311. Available from: https://www.cochranelibrary.com/cdsr/doi/10.1002/14651858.CD003311.pub3/ full doi: 10.1002/14651858.CD003311.pub3

2. Blomgren K, Zhu C, Hallin U, Hagberg H. Mitochondria and ischemic reperfusion damage in the adult and in the developing brain. Biochem Biophys Res Commun. 2003;304(3):551-9. doi: 10.1016/s0006-291x(03)00628-4

3. Robertson NJ, Tan S, Groenendaal F, van Bel F, Juul SE, Bennet L, et al. Which neuroprotective agents are ready for bench to bedside translation in the newborn infant? J Pediatr. 2012;160(4):544-52. doi: 10.1016/j.jpeds.2011.12.052

4. Penn AA, Gressens P, Fleiss B, Back SA, Gallo V. Controversies in preterm brain injury. Neurobiol Dis. 2016;92(A):90101. doi: $10.1016 /$ j.nbd.2015.10.012

5. Volpe JJ. Brain injury in premature infants: a complex amalgam of destructive and developmental disturbances. Lancet Neurol. 2009;8(1):110-24. doi: 10.1016/S1474-4422(08)70294-1

6. Buser JR, Maire J, Riddle A, Gong X, Nguyen T, Nelson K, et al. Arrested preoligodendrocyte maturation contributes to myelination failure in premature infants. Ann Neurol. 2012;71(1):93-109. doi: 10.1002/ana.22627

7. Back SA. Cerebral white and gray matter injury in newborns: new insights into pathophysiology and management. Clin Perinatol. 2014;41(1):1-24. doi: 10.1016/j.clp.2013.11.001

8. Thornton C, Leaw B, Mallard C, Nair S, Jinnai M, Hagberg H. Cell death in the developing brain after hypoxiaischemia. Front Cell Neurosci [Internet]. 2017[cited 2019 May 27];11:248. Available from: https://www.frontiersin.org/ articles/10.3389/fncel.2017.00248/full

9. Galluzzi L, Vitale I, Aaronson SA, Abrams JM, Adam D, Agostinis, P, et al. Molecular mechanisms of cell death: recommendations of the Nomenclature Committee on Cell Death 2018. Cell Death Differ. 2018;25(3):486-541. doi: 10.1038/ s41418-017-0012-4

10. Galluzzi L, Bravo-San Pedro JM, Kroemer G. Organelle-specific initiation of cell death. Nat. Cell Biol. 2014;16(8):72836. doi: $10.1038 / \mathrm{ncb} 3005$

11. Hagberg H, Mallard C, Rousset CI, Thornton, C. Mitochondria: hub of injury responses in the developing brain. Lancet Neurol. 2014;13(2):217-32. doi: 10.1016/S1474-4422(13)70261-8

12. Boland B, Nixon RA. Neuronal macroautophagy: from development to degeneration. Mol Aspects Med. 2006;27(56):503-19. doi: 10.1016/j.mam.2006.08.009

13. Bendix I, Schulze C, Haefen C, Gellhaus A, Endesfelder S, Heumann R, et al. Erythropoietin modulates autophagy signaling in the developing rat brain in an in vivo model of oxygen-toxicity. Int J Mol Sci. 2012;13(10):12939-51. doi: $10.3390 /$ ijms 131012939

14. Choi AM, Ryter SW, Levine B. Autophagy in human health and disease. N Engl J Med. 2013;368(7):651-62. doi: 10.1056/NEJMra1205406

15. Wang Y, Han R, Liang ZQ, Wu JC, Zhang XD, Gu ZL, et al. An autophagic mechanism is involved in apoptotic death of rat striatal neurons induced by the non-N-methyl-Daspartate receptor agonist kainic acid. Autophagy. 2008;4(2):214-26. doi: 10.4161 /auto. 5369

16. Klionsky DJ, Abdelmohsen K, Abe A, Abedin MJ, Abeliovich H, Acevedo Arozena A, et al. Guidelines for the use and interpretation of assays for monitoring autophagy (3rd Edition). Autophagy. 2016;12(1):1-222. doi: 10.1080/15548627.2015.1100356

17. Puyal J, Ginet V, Grishchuk Y, Truttmann AC, Clarke PGH. Neuronal autophagy as a mediator of life and death: contrasting roles in chronic neurodegenerative and acute neural disorders. Neuroscientist. 2012;18(3):224-36. doi: $10.1177 / 1073858411404948$

18. Uchiyama Y, Shibata M, Koike M, Yoshimura K, Sasaki M. Autophagy-physiology and pathophysiology. Histochem Cell Biol. 2008;129:407-20.

19. Clarke PG, Puyal J. Autophagic cell death exists. Autophagy. 2012;8(6):867-69. doi: 10.4161/auto.20380

20. Marino G, Niso-Santano M, Baehrecke EH, Kroemer G. Self-consumption: the interplay of autophagy and apoptosis. Nat Rev Mol Cell Biol. 2014;15(2):81-94. doi: 10.1038/nrm3735

21. Juul SE, Pet GC. Erythropoietin and neonatal neuroprotection. Clin Perinatol. 2015;42(3):469-81. doi: 10.1016/j. clp.2015.04.004

22. Wu Y, Song J, Wang Y, Wang X, Culmsee C, Zhu C. The potential pole of ferroptosis in neonatal brain injury. Front Neurosci. 2019;13:115. doi: 10.3389/fnins.2019.00115

23. Chen Q, Tang J, Tan L, Guo J, Tao Y, Li L, et al. Intracerebral hematoma contributes to hydrocephalus after intraventricular hemorrhage via aggravating iron accumulation. Stroke. 2015;46(10):2902-8. doi: 10.1161/ STROKEAHA.115.009713

24. Sun Y, Calvert JW, Zhang JH. Neonatal hypoxia/ischemia is associated with decreased inflammatory mediators after erythropoietin administration. Stroke. 2005;36(8):1672-8. doi: 10.1161/01.STR.0000173406.04891.8c

25. Dame C, Juul SE, Christensen RD. The biology of erythropoietin in the central nervous system and its neurotrophic and neuroprotective potential. Biol Neonate. 2001;79(3-4):228-35. doi: 10.1159/000047097

26. Fischer HS, Reibel NJ, Bührer C, Dame C. Prophylactic early erythropoietin for neuroprotection in preterm infants: a meta-analysis. Pediatrics[Internet]. 2017[cited 2019 Sep 5];139(5):e20164317. Available from: https://pediatrics. aappublications.org/content/139/5/e20164317.long 
27. Juul SE, Comstock BA, Wadhawan R, Mayock DE, Courtney SE, Robinson T, et al. A randomized trial of erythropoietin for neuroprotection in preterm infants. N Engl J Med. 2020;382(3):233-43. doi: 10.1056/NEJMoa1907423

28. Razak A, Hussain A. Erythropoietin in perinatal hypoxic-ischemic encephalopathy: a systematic review and metaanalysis. J Perinat Med. 2019;47(4):478-89. doi: 10.1515/jpm-2018-0360

29. Wu YW, Mathur AM, Chang T, McKinstry RC, Mulkey SB, Mayock DE, et al. High-dose erythropoietin and hypothermia for hypoxic-ischemic encephalopathy: a phase II trial. Pediatrics[Internet]. 2016[cited 2019 Oct 9];137(6):e20160191. Available from: https://pediatrics.aappublications.org/content/137/6/e20160191.long

30. Zhu C, Kang W, Xu F, Cheng X, Zhang Z, Jia L, et al. Erythropoietin improved neurologic outcomes in newborns with hypoxic-ischemic encephalopathy. Pediatrics[Internet]. 2009[cited 2019 Oct 9];124(2):e218-26. Available from: https:// pediatrics.aappublications.org/content/124/2/e218.long

\section{ПЕРИНАТАЛЬНА АСФІКСІЯ: ВАРІАНТИ ЗАГИБЕЛІ КЛІТИН I НЕЙРОПРОТЕКТИВНІ ВЛАСТИВОСТІ ЕРИТРОПОЕТИНУ}

\section{Л.Д. Танцюра}

\author{
Національна медична академія післядипломної \\ освіти імені П. Л. Шупика \\ MO3 України \\ (м. Київ, Україна)
}

\section{Резюме}

Перинатальна асфіксія $€$ істотним чинником ризику розвитку неврологічного дефіциту i когнітивних порушень у новонароджених дітей. У гострому періоді, після перенесеної гіпоксіїішемії, в головному мозку відбувається необоротна загибель частини клітин за типом некрозу. Пошкоджені таким чином клітини вже не можуть бути відновлені. У другу фазу ушкодження, яка обумовлена вторинною енергетичною недостатністю, варіанти загибелі клітин включають апоптоз, аутофагію, партанатос і ферроптоз. Ці типи руйнування клітин $є$ регульованими, вони можуть модулюватися, у тому числі й фармакологічними засобами. Препаратом, який продемонстрував свої нейропротективні властивості та поліпшення нейро-когнітивних результатів у новонароджених дітей після перенесеної гіпоксії-ішемії, виявився еритропоетин. Результати досліджень серед недоношених дітей досить суперечливі. Поліпшення когнітивного розвитку недоношених дітей при ранньому профілактичному призначенні рекомбінантного людського еритропоетину отримано у дітей з гестаційним віком понад 28-м тижнів. У глубоконедоношених дітей, народжених в терміні менше 28-ми тижнів гестації, застосування еритропоетину не вплинуло на неврологічний розвиток або летальність при оцінці к 2-х річному віку. У доношених новонароджених застосування еритропоетину в ранні терміни після перенесеної гіпоксії-ішемії скорочує ризик розвитку церебрального паралічу i когнітивних порушень. Дослідження, що тривають, покликані отримати інформацію про вплив раннього використання еритропоетину на результати як недоношених, так i доношених новонароджених дітей при поєднанні еритропоетину та лікувальної гіпотермії.

Ключові слова: еритропоетин; ураження головного мозку; нейропротекція; новонароджені діти; гіпоксично-ішемічна енцефалопатія; апоптоз; некроз; аутофагія.

\section{PERINATAL ASPHYXIA: THE CELL DEATH MECHANISMS AND THE NEUROPROTECTIVE EFFECTS OF ERYTHROPOIETIN}

\section{L.D. Tantsiura}

\author{
Shupyk National Medical Academy of \\ Postgraduate Education Ministry of Health of \\ Ukraine \\ (Kyiv, Ukraine)
}

\section{Summary}

Perinatal asphyxia is a major factor for the developmentof long-term neurological deficit and cognitive disorders in neonates. Brain shows signs of irreversible cell death (necrosis) after hypoxic-ischemic injury during the acute period. Damaged cells cannot be regenerated in future. Mechanisms of cell death caused by secondary energy deficiency during the second phase of damage include apoptosis, autophagy, parthanatos, and ferroptosis. This type of cell destruction can be regulated and modulated by means of pharmacological agents. Erythropoietin was a medication to show its neuroprotective properties and improve neurocognitive outcomes in newborns with hypoxia-ischemia. Evidence of its effectiveness in preterm infants is contradictory. Recent meta-analysis shown, that early prophylactic administration of recombinant human erythropoietin improved the cognitive development of very preterm infants without affecting other neurodevelopmental outcomes. However, the use of erythropoietin didn't affect the neurological development or death rate among extremely preterm infants with a gestational age of less than 28 weeks compared to 2 -year-olds. The use of erythropoietin early after hypoxia-ischemia in full-term infants reduced the risk of cerebral palsy and cognitive disorders. Ongoing studies are aimed at providing information about effect of erythropoietin use alongside with therapeutic hypothermia both on preterm and full-term newborns.

Keywords: erythropoietin; brain injury; neuroprotection; neonates; hypoxic ischemic encephalopathy; apoptosis; necrosis; autophagy. 
Контактна інформація:

\section{Танцюра Людмила Дмитрівна}

кандидат медичних наук, доцент кафедри

дитячої анестезіології Національної

медичної академії післядипломної освіти

імені П. Л. Шупика МОЗ України (м. Київ,

Україна)

Контактна адреса:

вул. Дорогожицька, 9, м. Київ, 04112 , Україна

Контактний телефон:

+38 (063) 1140389

e-mail: nicu72.anesth@gmail.com

ORCID ID: 0000-0002-8294-4122

Researcher ID: https://publons.com/

researcher/3287248/liudmyla-tantsiura/Web of

Science ResearcherID AAH-4925-2019
Контактная информация:

Танцюра Людмила Дмитриевна

кандидат медицинских наук, доцент кафедры

детской анестезиологии Национальной

медицинской академии последипломного

образования имени П. Л. Шупика МЗ Украинь

(г. Киев, Украина)

Контактный адрес:

ул. Дорогожицкая, 9, г. Киев, 04112, Украина

Контактный телефон:

+38 (063) 1140389

e-mail: nicu72.anesth@gmail.com

ORCID ID: 0000-0002-8294-4122

Researcher ID: https://publons.com/

researcher/3287248/liudmyla-tantsiura/Web of

Science ResearcherID AAH-4925-2019
Contact Information:

Ludmila Tantsiura

PhD, Associate Professor of the Department of Pediatric anesthesiology and critical care, Shupyk National Medical Academy of Postgraduate Education, (Ukraine, Kyiv)

Contact address:

9 Dorohozhytska str., Kyiv, 04112 Ukraine

\section{Phone:}

+38 (063) 1140389

e-mail: nicu72.anesth@gmail.com

ORCID ID: 0000-0002-8294-4122

Researcher ID: https://publons.com/

researcher/3287248/liudmyla-tantsiura/Web of

Science ResearcherID AAH-4925-2019 